\title{
A Histopathologic Analysis of 50 Eyes Primarily Enucleated for Retinoblastoma in a Tertiary Cancer Center in Jordan
}

\section{Ürdün'de Üçüncü Basamak Kanser Merkezinde Retinoblastoma Nedeniyle Primer Enükleasyon Uygulanan 50 Gözün Histopatolojik Incelemesi}

\author{
Yacoub A YOUSEF ${ }^{1}$, Yasmin HAJJA ${ }^{1}$, Ibrahim NAWAISEH ${ }^{1}$, Mustafa MEHYAR ${ }^{1}$, lyad SULTAN ${ }^{2}$, \\ Rasha DEEBAJAH ${ }^{2}$, Khalil RAWASHDEH ${ }^{1}$, Samer KHURMA ${ }^{1}$, Imad JARADAT ${ }^{3}$, Maysa AL-HUSSAINI ${ }^{4}$
}

Department of ${ }^{1}$ Surgery, ${ }^{2}$ Pediatrics, ${ }^{3}$ Radiotherapy and ${ }^{4}$ Pathology and Laboratory Medicine, King Hussein Cancer Center, AMMAN, JORDAN

\section{ABSTRACT}

Objective: To analyze the histopathologic features of the eyes with intraocular retinoblastoma primarily treated by enucleation in a tertiary cancer center in Jordan.

Material and Method: A retrospective case series of 50 eyes for 49 patients who had pathologically confirmed retinoblastoma after enucleation as primary therapy. The main outcome measures included demographics, laterality, international classification of intraocular retinoblastoma, choroid invasion, optic nerve invasion, anterior chamber invasion, and tumor differentiation.

Results: The median age at enucleation was 30 months. Twenty-seven (55\%) patients were males, and 19 (39\%) patients had bilateral retinoblastoma. High risk pathological features were seen as massive choroid invasion in $9(18 \%)$ eyes, post-laminar optic nerve invasion in $7(14 \%)$ eyes, and anterior chamber, iris or ciliary body invasion in $7(14 \%)$ eyes. Thirty-seven $(74 \%)$ tumors were well/moderately differentiated, and $13(26 \%)$ were poorly differentiated. Poorly differentiated tumors presented later (median 31 months) than well/ moderately differentiated tumors (26 months) and were associated with a higher incidence of high-risk pathological features. No single ICRB group C eye had high-risk pathological features, while $17 \%$ and $4 \%$ of group D eyes and $28 \%$ and $33 \%$ of group E eyes had massive choroid invasion and post-laminar optic nerve invasion, respectively. Eighteen (36\%) patients received adjuvant chemotherapy for high risk pathological features, and at median follow up of 40 months, no single case had metastasis or was dead.

Conclusion: Our pathologic findings were similar to the developed world. They were supportive of the predictive power of the international classification of retinoblastoma staging system for the likelihood of high risk pathological features. Poorly differentiated tumors were associated with a higher incidence of high risk pathological features than well/moderately differentiated tumors.

Key Words: Choroid, Optic nerve, Retinoblastoma, Eye
(Turk Patoloji Derg 2014, 30:171-177)

Received : 07.03.2014 Accepted : 28.04.2014
ÖZ

Amaç: Ürdün' de üçüncü basamak kanser merkezinde primer olarak enükleasyon ile tedavi edilen intraoküler retinoblastomalı gözlerin histopatolojik özelliklerinin araştırılması.

Gereç ve Yöntem: Primer tedavi olarak enükleasyon uygulandıktan sonra patolojiyle retinoblastoma tanısı alan 49 hastaya ait 50 gözden oluşan retrospektif olgu serisi. Demografik bulgular, lateralite, Uluslararası Retinoblastoma Sinıflaması, koroid invazyon, optik sinir invazyonu, ön kamera invazyonu ve tümör farklılaşması ana sonuç verileri olarak dahil edildi.

Bulgular: Enükleasyon sırasında ortalama yaş 30 aydı. Yirmi yedi (\%55) hasta erkekti ve 19 (\%39) hastanın bilateral retinoblastoması vardı. Yüksek riskli patolojik özellikler; 9 (\%18) gözde massif koroid invazyonu, 7'sinde (\%14) post-laminar optik sinir invazyonu ve 7'sinde (\%14) ön kamera, iris veya silier cisimcik invazyonu șeklindeydi. Otuz yedi (\%74) tümör iyi/orta derecede diferansiye ve 13 (\%26) az diferansiye idi. Az diferansiye tümörler (ortalama 31 ay), iyi/orta derecedeki tümörlere göre daha geç (ortalama 26 ay) ortaya çıkmakta ve yüksek riskli patolojik özellikler ile daha sıkı ilişki göstermektedir. Uluslararası Retinoblastoma Sınıflandırmasına göre grup D olanların $\% 17$ ve $\% 4$ ünde, grup E olanların \%28 ve \%33'ünde sırasıly massif koroid invazyonu ve post-laminar optik sinir invazyonu varken, grup C olanlarda ise yüksek riskli patolojik özellik yoktu. On sekiz (\%36) hasta yüksek riskli patolojik özellikler için adjuvan kemoterapi aldı ve 40 aylık ortalama takip süresince hiçbir olgunun metastazı yoktu ve hiçbiri ölmemişti.

Sonuç: Sonuçlarımız, gelişmiş ülkelere benzerdir. Yüksek risk faktörleri için Uluslararası Retinoblastoma Sınıflandırma evreleme sisteminin öngörü değerini destekleyicidir. İyi/orta derecede diferansiye tümörlere göre az diferansiye tümörler, yüksek risk faktörleri ile daha sıkı ilişkilidir.

Anahtar Sözcükler: Koroid, Optik sinir, Retinoblastoma, Göz

Correspondence: Maysa AL-HUSSAİNi

King Hussein Cancer Center, 02 Queen Rania Al-Abdullah Street,

P.O. Box 1269, Al-Jubaiha, AMMAN, 11941, JORDAN

E-mail: mhussaini@khcc.jo Phone: +096265300460 


\section{INTRODUCTION}

Retinoblastoma (RB), a rare tumor arising from the inner nuclear layer of the retina, is the most common primary intraocular malignancy in childhood and infancy. The incidence is estimated at about 1 in 15,000 to 20,000 live births(1-4).

The International Classification of RB (ICRB) (5) emerged in 2005, and staged RB according to tumor size and the presence and extent of tumor seeding (Table I). ICRB staging has been shown to assist in predicting those who are likely to be cured by chemoreduction and focal therapy. With the multidisciplinary therapeutic approach (chemotherapy, thermal therapy, cryotherapy, and radiotherapy), ocular

Table I: International classification of retinoblastoma (ICRB) (5)

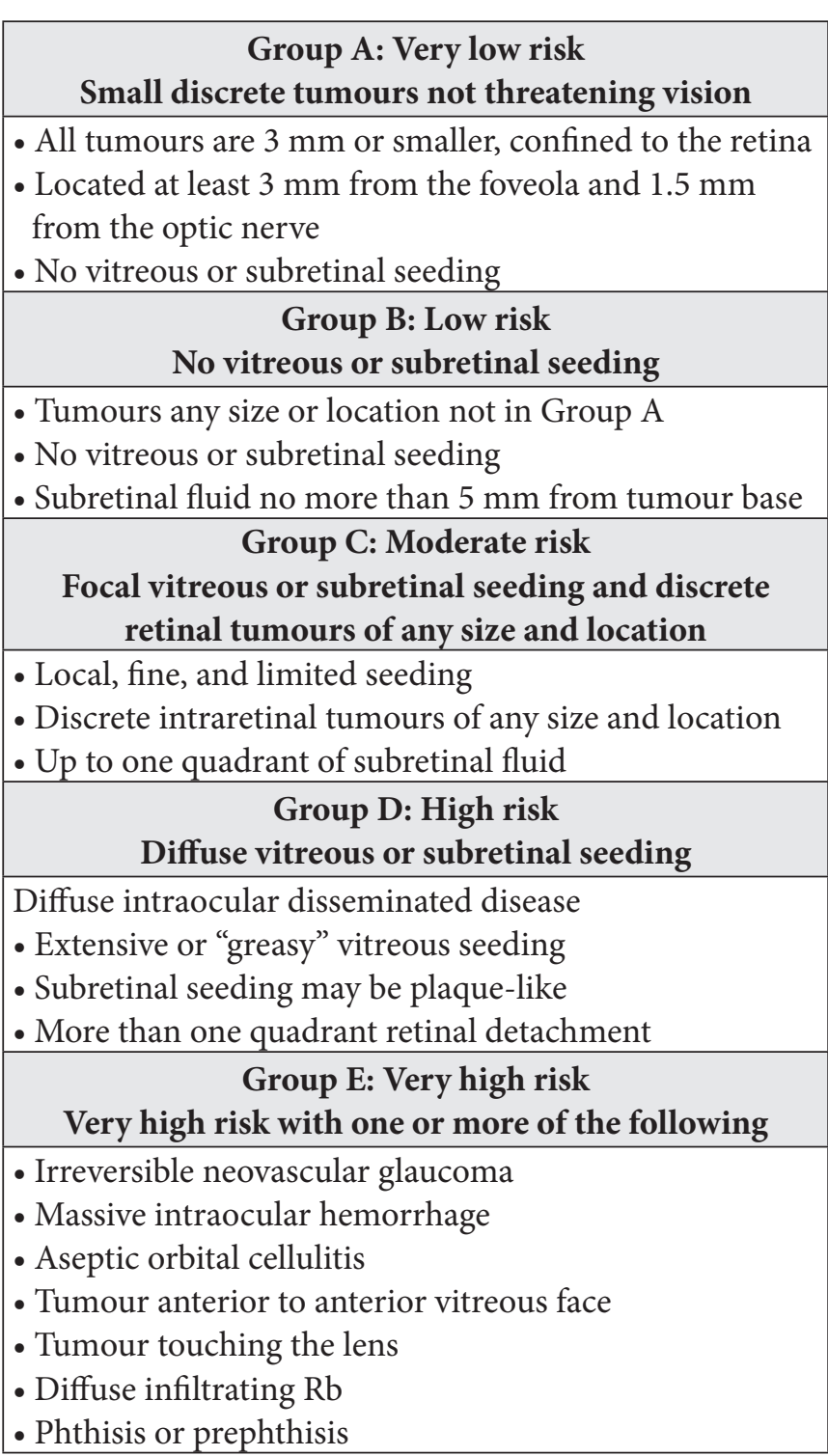

salvage is possible in group A through D intraocular tumors (5). However, in group E tumors (and group D in unilateral cases), enucleation remains the modality of choice (5-8).

Some histopathologic findings in enucleated eyes, designated as high-risk pathologic features (HRF), are associated with a higher risk of local recurrence and distant metastasis, and therefore need additional treatments such as adjuvant chemotherapy and external beam radiation. These HRF, which have been described, and debated, in the literature include tumor invasion of the anterior chamber, iris, ciliary body, massive choroid (more than $3 \mathrm{~mm}$ ), sclera, post-laminar portion of the optic nerve, combination of focal choroid invasion (less than $3 \mathrm{~mm}$ ) and optic nerve invasion, as well as extra-ocular tumor extension (9-15).

There are few studies that have evaluated HRF in eyes enucleated for advanced intraocular retinoblastoma from the developing world generally and from the MiddleEast specifically. Most of these reported higher incidences compared with studies reported from the developed world (15-21).

Herein, we report the results of a retrospective histopathologic analysis of eyes primarily enucleated for intraocular retinoblastoma at the single center for management of retinoblastoma in Jordan; one of the developing countries in the Middle East.

\section{MATERIALS and METHODS}

This study was approved by the Institutional Review Board. It was a retrospective case series of 50 eyes of 49 consecutive patients from January 2006 to November 2013 who had a clinical diagnosis of intraocular retinoblastoma, which was confirmed pathologically after primary enucleation. Selection required access to patients' medical and pathologic records. Pathology slides were reviewed when needed.

Data included patient's age, gender, laterality, age at enucleation, follow up period, initial international classification of retinoblastoma (ICRB) group (5), presence of choroid invasion (focal versus massive), level of optic nerve invasion, anterior chamber invasion, scleral and extra-scleral extension, tumor differentiation, metastasis, and mortality.

Inclusion and Exclusion Criteria: The eligibility criteria for inclusion were eyes with pathologic diagnosis of intraocular retinoblastoma treated initially by enucleation without receiving any focal therapy, chemotherapy or radiation therapy. Exclusion criteria included eyes that received any modality of treatment (focal therapy, chemotherapy, radiation therapy) before enucleation. In this series, 
enucleation was considered the first line treatment for all IRCB group E eyes, for unilateral ICRB group D eyes, and for unilateral ICRB group $C$ eyes with poor visual prognosis. Table I shows rational of the ICRB staging system (5).

Pathological Characteristics and Definitions: In this study, high risk pathologic features included massive choroid invasion, invasion of the post-laminar optic nerve, invasion of optic nerve resection line, scleral infiltration and anterior chamber invasion (iris infiltration, ciliary body infiltration) by tumor cells.

Choroid invasion was defined as one or more solid nests of tumor cells that fills or replaces the choroid and has pushing/ infiltrative borders. Tumors were divided into three groups; 1. No choroid invasion, 2. Focal choroid invasion: (less than $3 \mathrm{~mm}$ in the maximum diameter (width or thickness) and without touching the sclera), and 3. Massive choroid invasion (solid tumor nest $3 \mathrm{~mm}$ or more in maximum diameter; width or thickness and touches the inner surface of the sclera). Extent of optic nerve invasion was divided into three groups; 1 . No optic nerve invasion, 2. Laminar or pre-laminar optic nerve invasion, and 3. Post-laminar optic nerve invasion.

Tumors were divided into 2 groups according to level of differentiation; 1 . Well/moderately differentiated tumors (defined as tumors composed of small round blue cells, but show features of differentiation in the form of fluerettes, Flexner-Wintersteiner or Homer-Wright rosettes), and 2. Poorly differentiated tumors (defined as tumors composed of small round blue cell tumors that lacked any evidence of rosettes formation).

Endophytic tumor was defined as tumor that grows towards the vitreous cavity, and exophytic tumor was defined as tumor that grows outwards between the sensory retina and retinal pigment epithelium. When both patterns exist together, the growth pattern considered as combined.

In our center, indications for adjuvant chemotherapy after enucleation included optic nerve involvement posterior to the lamina cribrosa, massive choroid invasion, any degree of concomitant choroid and optic nerve involvement, anterior chamber seeding, ciliary body infiltration, iris infiltration, and scleral invasion

\section{RESULTS}

Between January 2006 and November 2013, 50 eyes for 49 patients underwent enucleation as primary treatment for intraocular retinoblastoma.
Demographics and Clinical Features: There were 27 males (55\%) and 22 females (45\%). There were 30 (61\%) unilateral and $19(39 \%)$ bilateral cases. One patient had bilateral enucleation as primary treatment. The median age at time of enucleation was 30 months (mean, 28 months; range, 5-61 months) for the whole group; 25 months (mean, 25 months; range, 5-50 months) for the unilateral cases and 31 months (mean, 33 months; range; 5 to 60 months) for the bilateral cases (Table II).

According to the international intraocular retinoblastoma classification (ICRB) (5); in this series, 8 (16\%) eyes were ICRB group C, 25 (50\%) eyes were ICRB group D, 17 (34\%) eyes were ICRB group E, and no one eye was ICRB group A or B (Table II). Neovascular glaucoma was seen in $14(28 \%)$ of cases.

Pathologic Features: Seventeen eyes (34\%) did not show any element of choroid, optic nerve, scleral, ciliary body, or anterior chamber invasion. Choroid invasion was seen in 22 (44\%) eyes; 9 (18\%) eyes had massive choroid invasion and 13 (26\%) had focal choroid invasion. Optic nerve invasion was seen in 23 (46\%) eyes; 16 (32\%) had laminar or prelaminar optic nerve invasion and $7(14 \%)$ eyes had post laminar optic nerve invasion. Anterior chamber invasion was seen in $7(14 \%)$ eyes, 3 (6\%) of them had ciliary body invasion. No single eye in this series had scleral or extrascleral tumor extension, and no one had tumor at the optic nerve resection margin.

Table II: Demographics and clinical features of 49 patients (50 eyes) primarily enucleated for retinoblastoma

\begin{tabular}{|l|c|}
\hline Number of patients & 49 \\
\hline Number of Eyes & 50 \\
\hline Males, no (\%) & $27(55)$ \\
\hline Females, no (\%) & $22(45)$ \\
\hline Age in months, median (range) & $30(5-62)$ \\
\hline Bilateral, no (\%) & $19(39)$ \\
\hline Unilateral, no (\%) & $30(61)$ \\
\hline ICRB ${ }^{\star}$ Group:- & \\
\hline Group A or B, no (\%) & $0(0)$ \\
\hline Group C, no (\%) & $8(16)$ \\
\hline Group D, no (\%) & $24(48)$ \\
\hline Group E, no (\%) & $18(36)$ \\
\hline Metastasis or Death & $0(0)$ \\
\hline Follow-up in months, median (range) & $40(3-100)$ \\
\hline
\end{tabular}

* ICRB (5): International Classification of Retinoblastoma 
Endophytic growth pattern was seen in 21 (42\%) eyes, exophytic growth pattern was seen in $15(30 \%)$ eyes, and combined growth pattern was seen in $14(28 \%)$ eyes (Figure 1A-D). No one eye had diffused infiltrative growth pattern. Thirty-seven (74\%) of the tumors were well/ moderately differentiated while 13 (26\%) eyes were poorly differentiated. Out of the 37 well/ moderately differentiated tumors, 14 (38\%) eyes had choroid invasion and $16(43 \%)$ eyes had optic nerve invasion, while out of the 13 poorly differentiated tumors, 8 (62\%) eyes had choroid invasion and $8(62 \%)$ eyes had optic nerve invasion. The median age at enucleation for the well/moderately differentiated tumors was 26 month, while it was 31 months for the poorly differentiated tumors (Table III).
Correlation Between International Classification and Histopathology: According to the ICRB classification; 8 (16\%) of eyes in this series were ICRB group C; one of the tumors (13\%) was poorly differentiated, 2 eyes $(25 \%)$ had choroid invasion (focal in both of them), and one eye (13\%) had pre-laminar optic nerve invasion. Twenty-four (48\%) eyes were ICRB group D; 2 (8\%) tumors were poorly differentiated, $8(34 \%)$ had choroid invasion, $4(17 \%)$ had massive choroid invasion, and 11 (48\%) had optic nerve invasion, only one (4\%) of which was post-laminar. Eighteen (36\%) eyes were ICRB group E; 10 (56\%) tumors were poorly differentiated, $12(67 \%)$ had choroid invasion, $5(28 \%)$ had massive choroid invasion, and 11 (61\%) had optic nerve invasion, 6 (33\%) of which were post-laminar. Table IV summarizes the correlation between the ICRB group and HRF.
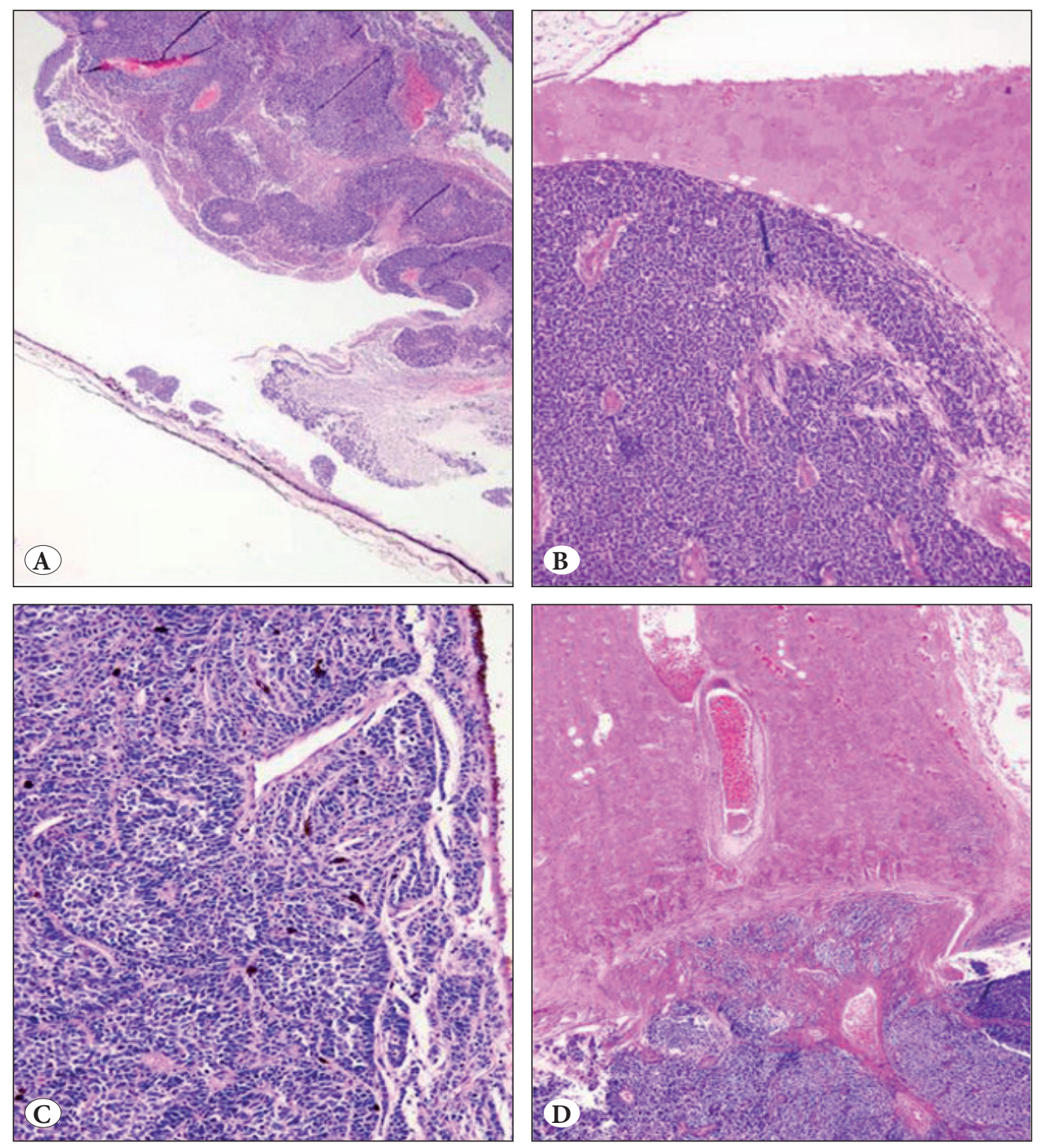

Figure 1: Different pathological features of intraocular retinoblastoma. A) Endophytic tumor growth pattern, with tumor growing towards the vitreous body away from the choroid and sclera (H\&E, x40),

B) Exophytic tumor growth pattern associated with (H\&E, x200), C) Massive choroid invasion defined as invasion of the choroid $>3 \mathrm{~mm}$ in any dimension (H\&E, x400x), D) Postlamina cribrosa optic nerve invasion can be seen in some eyes (H\&E, x200). 
Follow Up: The median follow up was 40 months (range; 3-100 months). Eighteen (36\%) cases received adjuvant chemotherapy; 11 (22\%) for massive choroid invasion and/or post-laminar optic nerve invasion, and 3(6\%) for concomitant focal choroid invasion and laminar optic nerve invasion, 7 (14\%) for anterior chamber, iris, or ciliary body invasion ( 3 of them had concomitant massive choroid or post-laminar optic nerve invasion). No single case in this series received radiation therapy, and no single case had metastasis or was dead at last date of follow up. No patients were lost to follow-up.

Table III: Histopathologic findings in 50 eyes primarily enucleated for retinoblastoma

\begin{tabular}{|c|c|}
\hline Histopathology & Eyes, no (\%) \\
\hline Tumor differentiation & $13(26)$ \\
\hline Poorly differentiated & $37(74)$ \\
\hline Well-differentiated & \\
\hline Tumor growth pattern & $21(42)$ \\
\hline Endophytic & $15(30)$ \\
\hline Exophytic & $14(28)$ \\
\hline Combined & \\
\hline Choroid invasion & $28(56)$ \\
\hline None & $13(26)$ \\
\hline Focal & $9(18)$ \\
\hline Massive & \\
\hline Optic Nerve invasion & $27(54)$ \\
\hline None & $16(32)$ \\
\hline Laminar or pre-laminar & $7(14)$ \\
\hline Post-laminar optic-nerve & $0(0)$ \\
\hline Resection margin & $7(14)$ \\
\hline Anterior chamber involvement & $3(6)$ \\
\hline Cilliary-body involvement & $14(28)$ \\
\hline Neovascularisation of the iris & $0(0)$ \\
\hline Scleral invasion & $0(0)$ \\
\hline Extra-ocular extension & \\
\hline
\end{tabular}

\section{DISCUSSION}

In this series, we examined the histopathology of 50 eyes primarily enucleated for retinoblastoma. Sixty-six percent of the eyes in our series showed some element of choroid, optic nerve, sclera, or anterior chamber tumor infiltration, while only $36 \%$ of the eyes showed HRF, and accordingly received adjuvant chemotherapy. No single eye received radiation therapy, and all patients were alive with no metastasis or orbital recurrence at a median follow-up of 40 months.

In the study by Zhao et al. (22), analysis of children with advanced intra ocular retinoblastoma showed lower disease-specific survival in those received pre-enucleation chemotherapy, since pre-enucleation chemotherapy can down-stage pathologic evidence of risk for extra-ocular extension, and therefore inadequate management by not receiving the needed adjuvant chemotherapy. In our series we included the eyes primarily enucleated without receiving pre-enucleation chemotherapy and thus the incidence of HRF reported in our series could truly represent the risk for metastasis. Similar to Zhao et al. results (22), no single case in our series (who did not receive pre-enucleation chemotherapy) had metastasis.

Tumor's differentiation was highly variable between different reports from the developing world. Many showed higher incidence of poorly differentiated (up to 80\%) compared to well differentiated tumors, probably due to late age of presentation (15-17). Most tumors (74\%) in our series as well as tumors reported by Filho et al. (95\%) (23) were well or moderately differentiated.

In our study, and similar to results reported by Eagle et al. (24) and Madhavan et al. (25), we observed that irrespective of laterality, well/moderately differentiated tumors presented earlier (median 26 months) than poorly differentiated tumors (31 months). In addition, and similar to results reported by Kashyap et al. (15), we noticed that poorly differentiated tumors were associated with higher

Table IV: Correlation between $\mathrm{ICRB}^{\star}$ group and $\mathrm{HRF}^{* *}$

\begin{tabular}{|l|r|c|c|c|c|c|c|}
\hline & & \multicolumn{2}{|c|}{ Choroid invasion } & \multicolumn{2}{c|}{ ON $^{* * *}$ invasion } & \multicolumn{2}{c|}{ Tumor differentiation } \\
\hline ICRB $^{\star}$ Group & No (\%) & Any & Massive & Any & Post-laminar & Well/Moderate & Poor \\
\hline C & $8(16)$ & $2(25)$ & $0(0)$ & $1(13)$ & $0(0)$ & $7(87)$ & $1(13)$ \\
\hline D & $24(48)$ & $8(33)$ & $4(17)$ & $11(44)$ & $1(4)$ & $22(92)$ & $2(8)$ \\
\hline E & $18(36)$ & $12(67)$ & $5(28)$ & $11(61)$ & $6(33)$ & $10(56)$ & $8(44)$ \\
\hline
\end{tabular}

${ }^{\star}$ ICRB (5): International Classification of Retinoblastoma

${ }^{* *}$ HRF: High risk pathological features

*** ON: Optic nerve 
Table V: Comparison of incidence (\%) of choroid and optic nerve invasion in various reported series

\begin{tabular}{|l|c|c|c|c|c|}
\hline \multicolumn{1}{|c|}{ Author } & Year & Country & $\begin{array}{c}\text { Choroid } \\
\text { invasion }\end{array}$ & $\begin{array}{c}\text { Massive choroid } \\
\text { invasion }\end{array}$ & $\begin{array}{c}\text { Optic nerve post Laminar or } \\
\text { resection margin invasion }\end{array}$ \\
\hline Wilson et al (10), & 2013 & USA & 61.5 & 25.7 & 14.9 \\
\hline Kashyap et al (15), & 2011 & India & 47.5 & 24.6 & 34.5 \\
\hline Yue et al (30), & 2011 & China & 86 & 24 & 24.6 \\
\hline Gupta et al (19), & 2009 & India & 40 & 27.5 & 40.4 \\
\hline Orellena et al (18), & 2009 & Venezuela & NA & 41 & 10.7 \\
\hline Eagle (24), & 2009 & USA & 16.5 & NA & 30 \\
\hline Khelfaoui et al (11), & 1996 & France & 42 & 11.6 & 6.5 \\
\hline Shields et al (28,29), & $1993 / 94$ & USA & 23 & NA & $\mathbf{1 4}$ \\
\hline Present study & $\mathbf{2 0 1 4}$ & Jordan & $\mathbf{4 4}$ & $\mathbf{1 8}$ & \\
\hline
\end{tabular}

incidence of HRF. These observations could be related to tumor progression and dedifferentiation from less aggressive, better differentiated tumors to more aggressive poorly differentiated tumors, a phenomenon that is well described in tumors in other organs like the thyroid gland and the esophagus $(15,23-27)$.

The reported incidence of the various histopathologic features in eyes enucleated for retinoblastoma is highly variable, and generally the incidence of choroid and optic nerve invasion in the developing world was higher than in the developed world (Table IV) $(10,11,15,18,19,24,28-30)$. The overall reported incidence of optic nerve involvement beyond the lamina cribrosa and at the resection margin ranged from $6.5 \%$ to $40 \%$, while the overall reported incidence of massive choroid invasion ranged from $12 \%$ to $41 \%$. In our series, $18 \%$ of eyes had massive choroid invasion and $14 \%$ had post laminar optic nerve invasion, which is comparable to the results reported from the developed world, and is less than the results reported from the developing world (Table V) $(10,11,15,18,19,24,28$ 30 ). The higher incidence of these risk factor in developing world might be related to later presentation (more advanced stage) in relation to the lower socioeconomic status and the delay in getting the needed treatment.

The Clinical International Classification (5) for intraocular retinoblastoma emerged in order to predict tumor response for chemotherapy, and of interest it was found to predict the likelihood of HRF as well (10). Wilson et al. (10) in an analysis of 67 eyes found that $50 \%$ of enucleated group $\mathrm{E}$ eyes had HRF while only $15 \%$ of Group D eyes had HRF $(\mathrm{p}=0.005)$. Similarly, in our series no single group $\mathrm{C}$ eye had HRF, $17 \%$ and $4 \%$ of group D eyes and $28 \%$ and $33 \%$ of group $\mathrm{E}$ eyes had massive choroid invasion and post laminar optic nerve invasion, respectively.
In conclusion, this is a retrospective histopathologic analysis of a 50 eyes treated by primary enucleation without receiving any previous chemotherapy or focal therapy. Although Jordan is a developing country, our pathologic findings and the incidence of HRF were similar to that reported in literature from the developed world. One plausible explanation is the centralization of this service to only a single referral tertiary center treating all retinoblastoma cases. This has lead to decrease the delay in diagnosis as well as getting an adequate management. Our pathologic findings revealed a predictive value of the ICRB staging system for the likelihood of HRF after enucleation where the more advanced ICRB stage at diagnosis was associated with higher incidence of HRF.

\section{REFERENCES}

1. International Incidence of Childhood Cancer, Vol. II. IARC Science Publ 1998;144:1-391.

2. Kivela T. The epidemiological challenge of the most frequent eye cancer: Retinoblastoma, an issue of birth and death. Br Jl Ophthalmol. 2009;93:1129-31.

3. Jaradat I, Yousef YA, Mehyar M, Sultan I, Khurma S, AlRawashded K, Wilson M, Qaddoumi I, Salem A, Alnawaiseh I. Retinoblastoma in Jordan: An epidemiological study (20062010). Hematol Oncol Stem Cell Theor. 2011;4:126-31.

4. Palazzi M, Abramson DH, Ellsworth RM. Endophytic vs. exophytic unilateral retinoblastoma: Is there any real difference? J Pediatr Ophthalmol Strabismus. 1990;27:255-8.

5. Linn Murphree A. Intraocular retinoblastoma: The case for a new group classification. Ophthalmol Clin North Am. 2005;18: 41-53, viii.

6. Shields CL, Mashayekhi A, Au AK, Czyz C, Leahey A, Meadows AT, Shields JA. The International Classification of Retinoblastoma predicts chemoreduction success. Ophthalmology. 2006;113:2276-80. 
7. Chan HS, Gallie BL, Munier FL, Beck Popovic M. Chemotherapy for retinoblastoma. Ophthalmol Clin North Am. 2005;18: 55-63, viii.

8. Kim JW, Abramson DH, Dunkel IJ. Current management strategies for intraocular retinoblastoma. Drugs. 2007;67:2173-85.

9. Kaliki S, Shields CL, Rojanaporn D, Al-Dahmash S, McLaughlin JP, Shields JA, Eagle RC Jr. High-risk retinoblastoma based on international classification of retinoblastoma: Analysis of 519 enucleated eyes. Ophthalmology. 2013;120:997-1003.

10. Wilson MW, Qaddoumi I, Billups C, Haik BG, RodriguezGalindo C. A clinicopathological correlation of 67 eyes primarily enucleated for advanced intraocular retinoblastoma. $\mathrm{Br} \mathrm{J}$ Ophthalmol. 2011;95:553-8.

11. Khelfaoui F, Validire P, Auperin A, Quintana E, Michon J, Pacquement H, Desjardins L, Asselain B, Schlienger P, Vielh P. Histopathologic risk factors in retinoblastoma: A retrospective study of 172 patients treated in a single institution. Cancer. 1996;77:1206-13.

12. Hungerford J. Factors influencing metastasis in retinoblastoma. Br J Ophthalmol. 1993;77:541.

13. Kopelman JE, McLean IW, Rosenberg SH. Multivariate analysis of risk factors for metastasis in retinoblastoma treated by enucleation. Ophthalmology. 1987;94:371-7.

14. Chantada GL, Casco F, Fandiño AC, Galli S, Manzitti J, Scopinaro M, Schvartzman E, de Dávila MT. Outcome of patients with retinoblastoma and postlaminar optic nerve invasion. Ophthalmology. 2007;114:2083-9.

15. Kashyap S, Sethi S, Meel R, Pushker N, Sen S, Bajaj MS, Chandra M, Ghose S. A histopathologic analysis of eyes primarily enucleated for advanced intraocular retinoblastoma from a developing country. Arch Pathol Lab Med. 2012;136:190-3.

16. Biswas J, Das D, Krishnakumar S, Shanmugam MP. Histopathologic analysis of 232 eyes with retinoblastoma conducted in an Indian tertiary-care ophthalmic center. J Pediatr Ophthalmol Strabismus. 2003; 40:265-7.

17. Vemuganti G, Honavar S, John R. Clinicopathological profile of retinoblastoma patients in Asian Indians. Invest Ophthalmol Vis Sci. 2000; 41:790.

18. Orellana ME, Fernandes BF, Arean C, Pifano I, Al-Kandari A, Burnier MN Jr. Clinical pathologic study of a cohort of patients with retinoblastoma from a developing country. J Pediatr Ophthalmol Strabismus. 2009;46:294-9.
19. Gupta R, Vemuganti GK, Reddy VA, Honavar SG. Histopathologic risk factors in retinoblastoma in India. Arch Pathol Lab Med. 2009;133:1210-4.

20. Owoeye JF, Afolayan EA, Ademola-Popoola DS. Retinoblastoma-a clinico-pathological study in Ilorin, Nigeria. Afr J Health Sci. 2006;13(1-2):117-23.

21. Ghassemi F, Chams H, Sabour S, Karkhaneh R, Farzbod F, Khodaparast M, Vosough P. Retinoblastoma: A Report from A Referral Center in Iran: 1979-2007. Iranian Journal of Ophthalmology. 2012;24:31-7.

22. Zhao J, Dimaras H, Massey C, Xu X, Huang D, Li B, Chan HS, Gallie BL. Pre-enucleation chemotherapy for eyes severely affected by retinoblastoma masks risk of tumor extension and increases death from metastasis. J Clin Oncol. 2011;29:845-51.

23. Filho JP, Correa ZM, Odashiro AN, Coutinho AB, Martins MC, Erwenne CM, Burnier MN Jr. Histopathological features and Pglycoprotein expression in retinoblastoma. Invest Ophthalmol Vis Sci. 2005;46:3478-83.

24. Eagle RC Jr. High-risk features and tumor differentiation in retinoblastoma: A retrospective histopathologic study. Arch Pathol Lab Med. 2009;133:1203-9.

25. Madhavan J, Ganesh A, Roy J, Biswas J, Kumaramanickavel G. The relationship between tumor cell differentiation and age at diagnosis in retinoblastoma. J Pediatr Ophthalmol Strabismus. 2008;45:22-5.

26. Helm J, Enkemann SA, Coppola D, Barthel JS, Kelley ST, Yeatman TJ. Dedifferentiation precedes invasion in the progression from Barrett's metaplasia to esophageal adenocarcinoma. Clin Cancer Res. 2005;11:2478-85.

27. Santos L, Loo C, Chandraratnam E, Gune S. Anaplastic carcinoma dedifferentiation of solid variant of papillary thyroid carcinoma. Pathology. 2004;36:196-211.

28. Shields CL, Shields JA, Baez K, Cater JR, De Potter P. Optic nerve invasion of retinoblastoma. Metastatic potential and clinical risk factors. Cancer. 1994;73:692-8.

29. Shields CL, Shields JA, Baez KA, Cater J, De Potter PV. Choroidal invasion of retinoblastoma: Metastatic potential and clinical risk factors. Br J Ophthalmol. 1993;77:544-8.

30. Yue H, Qian J, Xue K, Bi Y, Chen R, Han Y, Yuan Y. Histopathologic risk factors of retinoblastoma: A retrospective study of 104 enucleated eyes. Iranian Journal of Ophthalmology. 2011;23:51-9. 